\title{
An Empirical Study on the Relationship between Accounting Conservatism and Asset Impairment Recognition: Evidence from Companies in Taiwan
}

\author{
Mei-Chu HUANG ${ }^{1}$ \\ Chan-Chuan TING \\ $\mathrm{Yu}$-Jia CHEN ${ }^{3}$
}

\begin{abstract}
In this study, we investigate the impact of the conservatism of a company's financial statements on management's motivation to recognize asset impairment, and the impact of accounting conservatism on prior period impairment losses and gains on impairment reversal. The empirical results showed that a higher accounting conservatism level can reduce management manipulation for recognized more impairment losses in the prior period and then more gains on impairment reversal. That is, a higher level of accounting conservatism can reduce prior period impairment losses, recognized by managers, to make reserves to facilitate the recognition of gains on impairment reversal in a later period, to apparently 'improve' earnings.
\end{abstract}

KEYWORDS: asset impairment, gains on impairment reversal, accounting conservatism

JEL CLASSIFICATION: $M 1, M 2, M 4$

\section{INTRODUCTION}

To make financial statements more transparent, with reference to the International Accounting Standards (IAS) No. 36, the Statements of Financial Accounting Standards (SFAS) No.35 "Accounting for Assets Impairment" was promulgated in July 2004 in Taiwan, which changed the asset evaluation from a cost-oriented approach to a fair value-oriented approach, to increase the expression of the true state of assets and improve the conservatism of financial statements. SFAS No. 35 stipulates that, in the case of indications of possible impairment of a company's assets, an impairment test should be performed. When the book value of the assets of the company is higher than the recoverable amount of the assets, the assets may be impaired and the impairment losses should be recognized immediately to adjust the book value of the assets to the recoverable amount. Meanwhile, the company should also evaluate whether there was no or reduced impairment losses recognized in the previous year on the

\footnotetext{
${ }^{1}$ Department of Accounting, Chung Yuan Christian University, Taiwan, selenah@cycu.edu.tw (corresponding author)

2 Ph.D. Program in Business \& Department of Accounting, Chung Yuan Christian University, Taiwan, chuan2@mbox.cycu.edu.tw

3 Accounting Assistant, Lu-Chu Senior High School, Taiwan, panda581226@yahoo.com.tw
} 
financial reporting date. If so, the company should recognize the gains on impairment reversal within the reversals limitations.

Because the recognition of impairment loss only adjusts an accounting number, with no direct impact on cash flows, and managers are often involved in subjective judgments in assessing whether there is any indication of impairment, and managers may be tempted to manipulate earnings. Previous studies explore recognized impairment loss or gains on impairment reversal may result from earnings management motivation, in that managers regard recognized impairment losses as an important tool for the manipulation of profit or loss (Zucca \& Campbell, 1992). Some have argued that gains on impairment reversal is subject to the influence of the earnings motivations of the managers (Chen et al., 2007); however, other studies have suggested that recognized impairment loss is based on the actual economic conditions of the company (Chen et al., 2004).

There are many studies on asset impairment (Chang \& Yen, 2015; Chen et al. 2007; Dorina \& Sorin, 2016; Duh et al., 2009; Riedl 2004; Zhang et al., 2010), but few on the relationship between accounting conservatism and asset impairment. Accounting conservatism means that managers tend to choose an accounting method of lowering an asset's value when faced with two or more accounting methods in the evaluation of asset value. Moreover, gain recognition is stricter than the recognition of loss. Accounting conservatism has the function of addressing the problem of moral hazards generated by manager-stakeholder asymmetric information, asymmetric payoffs, limited horizons, and limited liability (Watts, 2003). Accounting conservatism can reduce manager's incentives to manipulate earnings, and mitigate the agency problem (LaFond \& Watts, 2008). When the agency problem is more serious, the level of earnings conservatism is higher (Kao et al., 2011). Chang (2006) compares the impact of accounting conservatism on the recognition of impairment loss before and after the implementation of SFAS No. 35, and find that the amount of asset impairment was higher when the company's level of conservatism was higher after the implementation of SFAS No.35. This suggests that conservatism may affect the company's recognized impairment losses. However, the reasoning behind the recognition of impairment loss by the managers is unclear, which is the main purpose this study investigate the relationship between accounting conservatism and asset impairment.

The empirical results showed that a higher accounting conservatism level can reduce management manipulation for recognized more impairment losses in the prior period and then more gains on impairment reversal. That is, a higher level of accounting conservatism can reduce prior period impairment losses, recognized by managers, to make reserves to facilitate the recognition of gains on impairment reversal in a later period, to apparently 'improve' earnings.

The remainder of this paper is organized as follows: Section 2 provides a literature review and the development of the hypotheses. Section 3 describes the research design, sample selection criteria and empirical models. Section 4 presents empirical results and their analysis. Section 5 offers conclusions.

\section{LITERATURE REVIEW AND HYPOTHESIS DEVELOPMENT}

\subsection{Determinants of Asset Impairment Recognition}

The real-world economic situation and earnings management behavior (e.g., taking a big bath, earnings smoothing) are determinants of asset impairment. Prior studies have find that managers have a motivation for speculative reporting, specifically, using asset impairment as a way of manipulating earnings. 
Zucca \& Campbell (1992) argue that asset impairment recognition is a type of earnings management and most companies recognize asset impairments when earnings are lower than normal. That is, the companies aim to "take a big bath". Alternatively, some companies recognize asset impairment when earnings are abnormally high, or in a case of windfall profits, so they aim to "smooth earnings". However, Rees et al. (1996) find that asset impairment recognition was caused by genuine changes in the economic environment and it reflect poor operating conditions rather than speculative behavior.

Chen et al. (2004) investigate the behaviors of voluntary disclosure asset impairment in the Chinese companies during the period 1998-1999, and find that a reduction in assets' book value communicated positive information to investors, allowing them to see that future performance would be improved. Using the economic asymmetric model, Yan \& Ding (2008) investigate whether the motivation for the recognition of impairment losses under different economic conditions (growth vs. recession) by categorizing motivations according to management incentives (e.g., taking a big bath, earnings smoothing, changes in high-level managers, debt contracting) and real economic factors (e.g., sales growth rate, earnings growth rate). They find that companies in an economic recession recognized asset impairment according to economic conditions, companies with poor earnings conditions conducted earnings management to take a big bath using asset impairment recognition, whereas companies with good earnings conditions conducted earnings management, smoothing earnings using asset impairment.

\subsection{Accounting Conservatism and Asset Impairment}

Accounting conservatism means that the accounting personnel tend to choose the more robust accounting method in the evaluation of assets and the recognition of gains and losses. Regarding unrealized profits and losses, the accountant may recognize the losses immediately and defer the gains. As unrealized losses require less verification than unrealized gains, the result is time asymmetry for bad and good news.

FASB (1980) viewed accounting conservatism as meaning that prudent judgment should be added in the estimation of financial statements under uncertain business operational or economic conditions, to prevent the overestimating of assets or revenue and the underestimating of liabilities or losses. However, the deliberate underestimating of net assets may result in the overestimation of future earnings.

Watts (2003) explains accounting conservatism is one of the most important explanations for the viewpoints of contracting and litigation, and argues that accounting conservatism is an efficient contracting mechanism for addressing the problem of asymmetric information of managers and stakeholders in signing contracts to reduce agency problems.

Kao et al., (2011) find that earnings conservatism can reduce the turnover of general managers. When the agency conflict is high, the demands on earnings conservatism are greater, suggesting that earnings conservatism can reduce agency problems. Moreover, asset overestimation may attract more attention from accounting regulatory agencies than the underestimation, and auditor tend to pay additional attention to asset overestimation in reviewing financial statements. Using the earnings-returns model proposed by Basu (1997), Chang's (2006) investigated results suggest that companies with a high level of conservatism will recognize more asset impairment after implementing SFAS No. 35. Lin et al., (2009) find that the shareholders tend to affect the major decisions of the company and exploit the interests of minor shareholders, thus lowering the level of accounting conservatism. These 
findings have suggested that accounting conservatism can reduce the reporting motivation of managers and the ability to manipulate earnings (LaFond \& Watts, 2008) as well as the timeliness of recognized bad or good news (Basu, 1997).

In line with the determinants of recognized asset impairments, as summarized in previous studies, and the relationship between accounting conservatism and recognized asset impairment, with the 'taking a big bath motivation' and the 'earnings smoothing motivation' as proxy variables of earnings management, motivational factors in accounting conservatism and the recognition of asset impairment by the management were investigated in this study. It was expected that accounting conservatism would be positively correlated with the recognition of asset impairment based on the 'taking a big bath motivation', while accounting conservatism and the recognition of asset impairment based on the 'earnings smoothing motivation' would be negatively correlated. Thus, $\mathrm{H}_{1}$ is proposed:

\section{H1: $_{1}$ Ceteris paribus, when firms with higher accounting conservatism level, the possibility will be reduced to manage earnings by recognized asset impairment.}

\subsection{Asset Impairment and Gain on Impairment Reversals}

The recognition of asset impairment or gains on impairment reversal by managers often involves subjective judgments. Thus, if the discretionary power of managers, or the opportunity to manipulate earnings on the part of the managers, is expanded, the managers may have incentives to pursue their own interests or 'improve' performance by recognized more impairment losses in a prior period to enable the recognition of a gain on impairment reversal when business performance is poorer or the company is at loss in the future. Similarly, when the business operational conditions are good, the company will store accruals in cookie jars. When the company is at a loss, such reserved accruals will then be converted into earnings to 'prevent' a loss, thereby misleading users of financial statements (Levitt, 1998). Thus, the reversal of long-term asset impairment is banned in Mainland China (Zhang et al., 2010). However, according to the provisions of IFRS, companies are allowed, to a limited extent, to recognize gains on impairment reversal.

Chen et al. (2007) find that gains on impairment reversal were subject to the influences of reporting motivations and economic factors, especially the reporting motivations. The speculative reporting motivation of the management can reduce the value relevance of the information regarding gains on impairment reversal.

Duh et al. (2009) investigate whether the reversal of impairment losses recognized in a previous year could provide managers with opportunities for earnings management. Their results reveal that the management tended to recognize more asset impairment losses to prevent a drop in earnings in a later period and to recover more impairment losses when necessary. Guo \& Tsai (2011) find that earnings and the recognition of gains on impairment reversal were significantly positively correlated when the earnings of the company were higher than expected. However, when the company earnings were lower than expected, the correlation was not significant, suggesting that managers will recognize gains on impairment reversal, and expand company earnings when current earnings are better, to satisfy investor expectations of earnings growth.

After recognizing asset impairment, the company further assesses the existence of the asset impairment recognized in the previous year at the financial report date. If external and internal 
sources of information may indicate that an impairment loss recognized for an asset, may no longer exist or may have decreased, the company may recognizes a gain on the 'reversals' of the impairment (SFAS No. 35). Thus, the amount of the recognized impairment losses in the prior period affects the amount of recognized gain on impairment reversals. The cause of such recognition can be attributable to the recognition of actual asset assessment conditions or other management incentives. For example, recognized more impairment losses recognized in the prior period and keeping reserves in advance can facilitate the improvement of earnings. Thus, from the definition of conservatism (to avoid the overestimation of assets and income, and the underestimation of expenses and losses), it would be expected that accounting conservatism would be negatively correlated with prior-period impairment losses and subsequent gains on impairment reversals. Thus, $\mathrm{H}_{2}$ is proposed:

$H_{2}$ : Ceteris paribus, when firms with higher accounting conservatism level, the manipulation of recognizing more impairment losses in a prior period and more gain on reversals of impairment in a later period can be reduced.

\section{RESEARCH DESIGN}

\subsection{Sample}

The Financial Accounting Standards Board (FASB) published SFAS No. 35 "Accounting for Assets Impairment" in July 2004, providing that it applied to financial statements with accounting year closing dates after December 31, 2005 (inclusive). Companies were also allowed to apply the standards in 2004 in advance. Because sample companies adopting the standards in advance had no data for impairment loss in the prior period, so we extract data from January 1, 2005 to December 31, 2016, except the turbulent years 2008-2009.

Financial data, and return rate data, to measure accounting conservatism, are sourced from the "TEJ Finance", and "TEJ Equity" modules of the Taiwan Economic Journal (TEJ) database. Our sample includes all Taiwanese listed and OTC-traded firms from January 1, 2005 to December 31, 2016, which without firms from the financial, insurance, and securities industries and firms lacking relevant variables in their financial data. Table 1 summarizes the sample selection procedures for asset impairment. There were 9,598 valid samples with asset impairment recognition. Companies of the electronics industry accounted for $50.93 \%$.

Table 2 summarizes the selection of samples with gains on impairment reversals. The year of impairment loss occurrence was estimated according to the year of impairment reversals, so as to observe the impact of the prior period asset impairment on the recognition of gains on impairment reversals. After excluding firms lacking financial data and companies with omissions, there were 1,219 valid data samples, consisting of companies from the electronics industry $(45.86 \%)$.

Table 1. Sample Selection for Asset Impairment

\begin{tabular}{|l|c|}
\hline $\begin{array}{l}\text { All firms during 2005-2016 without firms from the financial, insurance, and securities industries and } \\
\text { the turbulent years 2008-2009 }\end{array}$ & 18,141 \\
\hline Less: & $(8,543)$ \\
\hline Firms with missing data & 9,598 \\
\hline Final sample & \\
\hline
\end{tabular}

Source: authors 
Table 2. Sample Selection for Gains on Impairment Reversals

\begin{tabular}{|l|l|}
\hline $\begin{array}{l}\text { All firms during 2005-2016 without firms from the financial, insurance, and securities } \\
\text { industries and the turbulent years 2008-2009 }\end{array}$ & 1,561 \\
\hline Less: & \\
\hline Firms with missing data & $(342)$ \\
\hline Final sample & 1,219 \\
\hline
\end{tabular}

Source: authors

\subsection{Dependent Variables}

\subsubsection{Asset impairment (IMP)}

IMP is measured with recognized asset impairment loss divided by total assets (Riedl, 2004), if firm without being recognized as asset impairment, the value is 0 .

\subsubsection{Assets impairment reversal ratio $(R E V)$}

$\boldsymbol{R} \boldsymbol{E} \boldsymbol{V}$ is obtained by dividing the current gain on reversals of impairment by the total assets in the current year (Duh et al. 2009).

\subsection{Independent variables}

\subsubsection{Taking a big bath $(B A T H)$}

$\boldsymbol{B A T H}$ defined as dividing the change in earnings before asset impairment $\left(\Delta E_{i t}\right)$ divided by the total assets (Yang \& Wu, 2009). Change in earnings means the difference in net profit before tax of firm i between year $\mathrm{t}$ and year $\mathrm{t}-1$. If the change in earnings is smaller than the median of the negative values of change in earnings, it is measured by the change; otherwise, it is 0 .

\subsubsection{Earnings smoothing (SMOOTH)}

SMOOTH is measured like the method above. If the change in earnings is larger than the median of the positive values of earnings, then the value of SMOOTH is the change in value; otherwise, it is 0 .

\subsubsection{Earnings conservatism $(C O N)$}

The earnings conservatism value $(\boldsymbol{C O N})$ is measured by C_SCORE. C_SCORE is obtained by considering the firm characteristics (Basu, 1997; Khan \& Watts, 2009). This study made judgments according to the C_SCORE values of individual firms and the C_SCORE value of all sample firms. If the C_SCORE value of an individual firm was larger than the median of the C_SCORE values of all firms, the value of CON is 1 ; otherwise, it is 0 .

\subsubsection{Prior Period asset impairment ratio $\left(B E_{-} I M P_{i t}\right)$}

Because the gain on the reversals of asset impairment will be affected by the amount of the prior period asset impairment recognized, it is necessary to control prior period asset impairment ratio. $B E_{-} I M P_{i t}$ is measured as the impairment amount in the estimated year of prior period impairment divided by prior period total assets.

\subsection{Control variables}

\subsubsection{Prior period asset impairment $\left(I M P_{i t-1}\right)$}

Asset impairment recognized in the current period will be affected by the impairment losses of the prior period; thus, to control the impact of the prior period's impairment loss on the current impairment loss. $I M P_{i t-1}$ is measured as the prior year impairment losses recognized 
divided by the prior year total assets. If asset impairment was not recognized as such, the value is 0 .

\subsubsection{Change in average asset return rate $(\triangle R O A)$}

This variable is used to measure the company's business performance and the management's abilities to 'create' profits by using their assets. $\triangle R O A$ is measured by average asset return rates of the company in the 3 years before the current year.

\subsubsection{Market-to-book value ratio $(M T B)$}

Due to the rules of asset impairment, when the book value of assets is higher than the market value, asset impairment should be recognized immediately. Thus, the impact of this ratio on the recognition of asset impairment should be controlled. MTB is the division of the per share price of the company by the book value per share on the financial reporting date of the current year.

\subsubsection{Change in sales $(\triangle S A L E)$}

When the assets efficiency is in poor condition, productivity will be reduced, thus potentially affecting the sales. $\triangle S A L E$ is used to capture the capability of asset value reversals on the basis of accruals.

\subsubsection{Change in operating cash flow ratio $(\triangle O C F)$}

$\triangle O C F$ is used to capture the capability of asset value reversals on the basis of cash, this variable is measured with the current year operating cash flow minus the prior year's operating cash flow, then divided by total assets.

\subsubsection{Firm size (SIZE)}

The impact of firm size on business performance varies. Thus, it can affect the recognition of asset impairment, and it is used to control the effect of firm size. SIZE is measured by the natural logarithm of the total assets.

\subsubsection{Debt ratio $(L E V)$}

High debt ratios more readily attract the attention of creditors. Thus, when a firm recognizes asset impairment, it shows the company is addressing the problem, communicating positive information to creditors, and investors. So, when the debt ratio is higher, the company is more likely to recognize impairment losses (Zucca \& Campbell, 1992; Yan \& Ding, 2008). LEV is measured by dividing total long term liabilities by the total assets at the financial reporting date.

\subsubsection{Electronics industry (ELEC)}

After screening and selecting sample companies for testing asset impairment and gain on reversals of impairment, it was found that companies in the electronics industry accounted for more than $50 \%$ of the total sample. ELEC is used to control for any industry effect; when the company is of the electronics industry, the value is 1 ; otherwise, it is 0 .

\subsection{Empirical Model}

\subsubsection{Measurement of Conservatism}

In line with the previous studies (Basu, 1997; Khan \& Watts, 2009), we argued that the timeliness of the recognition of good and bad news is not symmetric; adopting conservatism will allow a company to immediately recognize bad news and reflect it in the earnings 
(LaFond \& Watts, 2008; Lin et al., 2009; Kao et al., 2011). Thus, regression equation (1) is used to measure the financial statement conservatism.

$X_{i t} / P_{i t}=\beta_{0}+\beta_{1} D R_{i t}+\beta_{2} R_{i t}+\beta_{3} R_{i t} * D R_{i t}+\varepsilon_{i t}$

where,

$X_{i t} / P_{i t}: \quad$ income before tax from continuing operations by firm i in year $\mathrm{t}$ deflated by market value at the beginning of the year $t$;

$D R_{i t}$ : $\quad$ A dummy variable: if $\mathrm{R}_{\text {it }}$ is negative, then $\mathrm{DR}_{\mathrm{it}}$ is 1 ; otherwise, it is 0 .

$R_{i t}: \quad \quad$ return rate of the firm $\mathrm{i}$ in year $\mathrm{t}$.

$\varepsilon_{i t}: \quad$ error term.

The coefficient of earnings against positive return (good news) will be reflected in $\beta_{2}$. When the return is negative (bad news), then it is $\beta_{2}+\beta_{3}$. Therefore, the coefficient of difference in the response to good and bad news is $\beta_{3}$. Then, if $\beta_{3}>0$, this means that the company financial condition are sound and conservative. However, Basu (1997) assumes that the conservatism of all companies in the same year is homogeneous, or that the conservatism of the same company will not change over time; thus it does not learn the conservatism status of other companies. To capture the conservatism of each company in various years, we referred to the estimation method of Khan \& Watts (2009). The method is based on the method of Basu using the good news response timeliness (G_Score) to represent $\beta_{2}$ and conservatism (C_Score) to represent $\beta_{3}$, and controlling for company characteristics, including SIZE for company size, MTB for market-to-book value ratio, and LEV for debt ratio. It is calculated using the following:

G_Score $=\beta_{2}=\mu_{1}+\mu_{2} S I Z E+\mu_{3} M T B+\mu_{4} L E V$

C_Score $=\beta_{3}=\lambda_{1}+\lambda_{2} S I Z E+\lambda_{3} M T B+\lambda_{4} L E V$

where,

SIZE: the natural logarithm of the total assets of the firm in year $t$;

MTB: firm i's market-to-book ratio, measured by the ratio of market value to stockholders' equity at the end of year;

LEV: firm i's total liabilities in year i deflated by stock market value in year $\mathrm{t}-1$.

By inputting Eq. (1a) and Eq. (1b) into regression equation (1), we can obtain the annual conservatism:

$$
\begin{aligned}
& X_{i} / P_{i}=\beta_{0}+\beta_{1} D R_{i}+R_{i}\left(\mu_{1}+\mu_{2} S I Z E_{i}+\mu_{3} M T B_{i}+\mu_{4} L E V_{i}\right) \\
& +R_{i} * D R_{i}\left(\lambda_{1}+\lambda_{2} S_{I Z E_{i}}+\lambda_{3} M T B_{i}+\lambda_{4} L E V_{i}\right) \\
& +\delta_{1} S_{I Z E_{i}}+\delta_{2} M T B_{i}+\delta_{3} L E V_{i}+\delta_{4} D R_{i} * S I Z E_{i} \\
& +\delta_{5} D R_{i} * M T B_{i}+\delta_{6} D R_{i} * L E V_{i}+\varepsilon_{i}
\end{aligned}
$$

Finally, by inputting the estimated values of $\mu_{i}$ and $\lambda_{i}$ (i=1 4) obtained using equation (2) into (1a) and (1b), we can obtain the conservatism of companies in each year. When $\beta_{3}>0$, it indicates that the company is conservative. 


\subsubsection{Verification of $\mathrm{H}_{1}$}

As the dependent variable (IMP) asset impairment ratio is limited, starting from zero, we used a Tobit regression in the empirical study. Below, we propose an empirical model regarding $\mathrm{H}_{1}$ :

where,

$$
\begin{aligned}
& I M P_{i t}=\alpha_{0}+\alpha_{1} \text { CON }_{i t}+\alpha_{2} \text { BATH }_{i t}+\alpha_{3} \text { SMOOTH }_{i t}+\alpha_{4} \text { BATH }_{i t} * \text { CON }_{i t} \\
& +\alpha_{5} \text { SMOOTH }_{i t} * \operatorname{CON}_{i t}+\propto_{6} I M P_{i t-1}+\propto_{7} \Delta R O A_{i t}+\propto_{8} \Delta S A L E_{i t} \\
& +\alpha_{9} \Delta O C F_{i t}+\alpha_{10} M T B_{i t}+\alpha_{11} L E V_{i t}+\alpha_{12} S I Z E_{i t}+\alpha_{13} E L E C_{i t} \\
& +\sum \alpha_{j} Y E A R_{i j t}+\varepsilon_{i} \ldots \ldots \ldots \ldots \ldots \ldots \ldots \ldots \ldots \ldots \ldots
\end{aligned}
$$
$I M P_{i t}$ :
the recognized impairment losses of firm $\mathrm{i}$ in year $\mathrm{t}$ deflated by total assets
$\operatorname{CON}_{i t}$ :
$B A T H_{i t}$ : at the end of year $t-1$, if asset impairment is not recognized, the value is 0 ; A dummy variable; 1 if the company is conservative, otherwise, it is 0 ; $\Delta E_{i t}$ means firm i's net profit before taxation change from year t-1 to year $\mathrm{t}$ deflated by total assets. If the change in earnings $\left(\Delta E_{i t}\right)<\Delta E_{i t}$ is below the median, $\mathrm{BATH}=\Delta E_{i t}$; otherwise, it is 0 ;

SMOOTH $H_{i t}$ If $\Delta E_{i t}>\Delta E_{i t}$ is above the median, then $\mathrm{SMOOTH}=\Delta E_{i t}$; otherwise, it is 0 ;

$I M P_{i t-1}$ : the recognized impairment losses of firm $i$ in year $t-1$ deflated by total assets

$\triangle R O A_{i t}$ at the end of year t-2; if asset impairment is not recognized, the value is 0 ; the average of firm' $i$ asset return rates in the 3 years before year $t$, and firm' $i$ assets return is measured by net profit before interest and after

$\triangle S A L E_{i t}:$ taxation in year $t$ deflated by total assets at the end of year $t$ )

$\triangle O C F_{i t}:$ The percentage change in firm i's net sales from year t- 1 to $t$;

$M T B_{i t}:$ The percentage change in firm i's operating cash flow from year t-1 to t; firm i's market-to-book ratio, measured by the ratio of market value to stockholders' equity at the end of year;

$L E V_{i t}$ :

$S I Z E_{i t}$ : firm i's total liabilities in year i deflated by stock market value in year t- 1 .

$E L E C_{i t}$ : the natural logarithm of the total assets of firm $\mathrm{i}$ in year $\mathrm{t}$.

$Y E A R_{i j t}$ : A Dummy variable: if the company is of the electronics industry, the value is 1 ; otherwise, it is 0 . Annual dummy variable: the year period was 2005-2016 except 2008-2009, so the 10 years are set as a dummy variable.

First, because the level of conservatism of the company can affect the amount of asset impairment recognition (Chang, 2006), in this study, it was expected that the variables of conservatism $\left(C O N_{i t}\right)$ and impairment loss would be positively correlated $\left(\alpha_{1}>0\right)$. When the company earnings performance is not as expected and cannot be supplemented by any other means, the management may tend to recognize all losses at once to enhance future earnings. Thus, the variable of taking a big bath $\left(B A T H_{i t}\right)$ is expected to be negative $\left(\alpha_{2}<0\right)$. When a company's earnings performance is better, to avoid too great fluctuations in earnings, the management will choose to recognize more impairment losses with the aim of smoothing earnings; thus, the coefficient of earnings smoothing $\left(\mathrm{SMOOTH}_{i t}\right)$ is expected to be positive $\left(\alpha_{3}>0\right)$.

In equation (3), We use the interaction term $\left(B A T H_{i t} * C O N_{i t}\right.$ and $\left.S M O O T H_{i t} * C O N_{i t}\right)$ to examine whether the motivation for recognized impairment losses is affected by the company's conservatism. When the company has serious agency problems, the management can easily be affected by management incentives to enhance the possibility of an untrue presentation of financial statements. LaFond \& Watts (2008) found that accounting 
conservatism can help corporate governance mechanisms and effectively reduce some agency problems (Kao et al., 2011). Thus, this study suggests that when a company's earnings performance is lower than the median of the negative value of changes in earnings, the management is more unlikely to recognize the impairment losses for the purpose of taking a big bath. Therefore, the interaction term $\left(B A T H_{i t} * C O N_{i t}\right)$ is expected to be positive $\left(\alpha_{4}>\right.$ 0 ); relatively speaking, when the company has excessive earnings, the management will be more unlikely to recognize the impairment losses for the purpose of conservatively reporting earnings. Thus, it is expected that the interaction term $\left(S_{M O O T H} H_{i t} * C O N_{i t}\right)$ would be negative $\left(\alpha_{5}<0\right)$. According to the expected results of the interaction term $\left(B A T H_{i t} *\right.$ $\left.\mathrm{CON}_{i t}\right)$, and $\left(\mathrm{SMOOTH}_{i t} * \mathrm{CON}_{i t}\right)$, it is inferred in $\mathrm{H}_{1}$ that companies with more conservative will be more likely to recognize asset impairment according to genuine economic conditions. We include change in average asset return rate $\left(\triangle R O A_{i t}\right)$, market-to-book value ratio $\left(M T B_{i t}\right)$, change in operating cash flow $\operatorname{ratio}\left(\triangle O C F_{i t}\right)$, and change in sales $\left(\triangle S A L E_{i t}\right)$ as control variables. When the operating performance is not good, the management will recognize more impairment losses (Francis et al., 1996). Thus, the coefficients for $\triangle R O A_{i t}, \triangle S A L E_{i t}$, and, $\triangle O C F_{i t}$ are expected to be negative $\left(\alpha_{7} 、 \alpha_{8}, \alpha_{9}<0\right)$. Similarly, when the market value of the company's assets is lower than the book value, the management will tend to recognize more asset impairment; thus, the coefficient of $M T B$ is expected to be negative $\left(\alpha_{10}<0\right)$.

Additionally, when the company has a relatively high debt ratio, this means that its financial status is relatively poor and, thus, it will tend to recognize more impairment losses to allow creditors to know that the company is dealing with the problem of asset impairment. Thus, the coefficient for $L E V_{i t}$ is expected to be positive $\left(\alpha_{11}>0\right)$.

Finally, when the firm size is relatively large, the managers will be affected by management incentives and conduct earnings management by taking advantage of asset impairment. The variables should be controlled and, thus, the coefficient of the variable $S I Z E_{i t}$ is expected to be negative $\left(\alpha_{12}<0\right)$.

\subsubsection{Verification of $\mathrm{H}_{2}$}

$$
\begin{aligned}
& R E V_{i t}=\theta_{0}+\theta_{1} C O N_{i t}+\theta_{2} B E_{I M P_{i t}}+\theta_{3} C O N_{i t} * B E_{I M P_{i t}}+\theta_{4} \Delta R O A_{i t} \\
& +\theta_{5} \Delta S A L E_{i t}+\theta_{6} \Delta O C F_{i t}+\theta_{7} M T B_{i t}+\theta_{8} L E V_{i t}+\theta_{9} S I Z E_{i t}+ \\
& \theta_{10} E L E C_{i t}+\varepsilon_{i} \ldots \ldots \ldots \ldots \ldots \ldots \ldots \ldots \text { (4) }
\end{aligned}
$$

$R E V_{i t}$ : gain on reversals of impairment of firm $\mathrm{i}$ in year $\mathrm{t}-1$ deflated by total assets at the end of year $\mathrm{t}$.

When a company's level of conservatism is higher, it means that the company is more unlikely to recognize gains. Consequently, the coefficient of the variable of conservatism $\left(C O N_{i t}\right)$ is expected to be negative $\left(\theta_{1}<0\right)$.

The motivation to recognize prior asset impairment may affect gain on reversals of impairment recognized in a later year. When the company has a motivation for earnings management, it will recognize more gain on reversals of impairment in later years (Duh et al., 2009). Thus, it is expected that the prior period asset impairment recognition and the later gain on reversals of impairment recognition would be positively correlated $\left(\theta_{2}>0\right)$.

In equation (4), we use the interaction term financial statement conservatism and the variable asset impairment $\left(C O N_{i t} * B E_{-} I M P_{i t}\right)$ to test whether the relationship between prior period impairment losses and gain on reversals of impairment recognition is affected by the level of company conservatism. As conservatism can reduce agency problems (Gao et al., 2011), 
information verification for recognized good news is stricter than for the recognition of bad news. Consequently, the coefficient for $C O N_{i t} * B E_{-} I M P_{i t}$ is expected to be negative $\left(\theta_{3}<\right.$ $0)$.

Additionally, for control variables, when sales growth rate $\left(\triangle S A L E_{i t}\right)$, operating cash flow ratio $\left(\triangle O C F_{i t}\right)$, change in average asset return rate $\left(\triangle R O A_{i t}\right)$, and market-to-book value $\left(M T B_{i t}\right)$ are higher, this means the capabilities to recover the assets are higher, so the amount of recognized gain on reversals of impairment will be more. As a result, the coefficients for $\triangle S A L E_{i t}, \triangle O C F_{i t}, M T B_{i t}$, and $\triangle R O A_{i t}$ are expected to be positive $\left(\theta_{4} \cdot \theta_{5} \cdot \theta_{6} \cdot \theta_{7}>0\right)$. Managers will choose accounting methods to improve net value, to avoid a debt contract default (Yang \& Ding, 2008). Thus, when the debt ratio of the company is higher, the managers are more likely to recognize gain on reversals of impairment, so the coefficient of variable $L E V_{i t}$ is expected to be positive $\left(\theta_{8}>0\right)$.

Finally, when company size is larger, the managers will have more options in choosing the accounting method, so they are more likely to have the motivation of earnings management to recognize more gain on reversals of impairment. The coefficient of variable for $S I Z E_{i t}$ is thus expected to be positive $\left(\theta_{9}>0\right)$.

\section{EMPIRICAL RESULTS}

\subsection{Financial Statement Conservatism}

To measure conservatism, the estimation method proposed by Khan \& Watts (2009) was used. After obtaining the coefficients of $\mu_{1} \sim \mu_{4}$ and $\lambda_{1} \sim \lambda_{4}$ from Table 3, we entered them into the linear functions of (1a) and (1b) to obtain G_SCORE (representing the responsive timeliness of good news) and C_SCORE (representing conservatism) to learn about the level of conservatism of each company in each year. Table 4 provides descriptive statistics for firm's conservatism measurement. The mean of G_SCORE and C_SCORE is -0.0004 and 0.0039 respectively, where the mean of C_SCORE is larger than the median. Thus, it can be concluded that the conservatism of the financial statements of the listed and OTC-traded sample companies during the period 2005-2016 was at a medium level.

Table 3. Results of the estimation method

\begin{tabular}{|l|c|c|c|c|}
\hline \multicolumn{1}{|c|}{ Variables } & & Coefficient & t-statistic & P-value \\
\hline INTERCEPT & & -3.8037 & -6.09 & 0.00 \\
\hline $\mathrm{DR}$ & $\mu_{1}$ & -0.7370 & -0.73 & 0.46 \\
\hline $\mathrm{R}$ & $\mu_{2}$ & -0.0050 & -0.74 & 0.46 \\
\hline $\mathrm{R} * \mathrm{SIZE}$ & $\mu_{3}$ & 0.0003 & 0.98 & 0.32 \\
\hline $\mathrm{R} * \mathrm{MTB}$ & $\mu_{4}$ & -0.0001 & $-1.69^{*}$ & $0.09^{*}$ \\
\hline $\mathrm{R} * \mathrm{LEV}$ & $\lambda_{1}$ & 0.0033 & 2.27 & 0.02 \\
\hline $\mathrm{R} * \mathrm{DR}$ & $\lambda_{2}$ & -0.0030 & -1.19 & $0.03^{* *}$ \\
\hline $\mathrm{R} * \mathrm{DR} * \mathrm{SIZE}$ & $\lambda_{3}$ & 0.0019 & 1.50 & 0.23 \\
\hline $\mathrm{R} * \mathrm{DR} * \mathrm{MTB}$ & $\lambda_{4}$ & 0.1086 & 1.24 & 0.13 \\
\hline $\mathrm{R} * \mathrm{DR} * \mathrm{LEV}$ & & 0.3483 & 8.36 & 0.21 \\
\hline SIZE & & 0.1598 & 2.39 & 0.00 \\
\hline MTB & & -3.4491 & $-5.51^{* * *}$ & 0.01 \\
\hline LEV & & &
\end{tabular}




\begin{tabular}{|l|l|c|c|c|}
\hline \hline \multicolumn{1}{|c|}{ Variables } & & Coefficient & t-statistic & P-value \\
\hline DR*SIZE & & 0.0512 & 0.77 & 0.44 \\
\hline DR*MTB & & -0.0332 & -0.35 & 0.72 \\
\hline DR*LEV & & -3.560 & -1.35 & 0.17 \\
\hline $\mathrm{N}$ & & 12154 & & \\
\hline Adj. $R^{2}$ & & 0.1144 & & \\
\hline
\end{tabular}

Source: authors

Table 4. Descriptive statistics for firm's conservatism measurement

\begin{tabular}{|l|l|l|l|l|l|}
\hline & \multicolumn{1}{|c|}{ Mean } & \multicolumn{1}{|c|}{ Median } & \multicolumn{1}{|c|}{ Max } & \multicolumn{1}{|c|}{ Min } & \multicolumn{1}{c|}{ Std. dev. } \\
\hline G_SCORE & 0.0097 & 0.0084 & 0.0533 & -0.0201 & 0.0001 \\
\hline C_SCORE & 0.0125 & 0.0136 & 0.0748 & -0.0511 & 0.0161 \\
\hline
\end{tabular}

Note: (1a) G_Score $=\beta_{2}=\mu_{1}+\mu_{2} S I Z E+\mu_{3} M T B+\mu_{4} L E V$ 。

(1b) C_Score $=\beta_{3}=\lambda_{1}+\lambda_{2} S I Z E+\lambda_{3} M T B+\lambda_{4} L E V$ 。

Source: authors

\subsection{Asset Impairment Loss and Financial Statement Conservatism}

\subsubsection{Descriptive statistics}

Table 5 shows the descriptive statistics of variables of $\mathrm{H}_{1}$. The mean of asset impairment ratio $\left(I M P_{i t}\right)$ is 0.0016 , and the mean of financial statement conservatism $\left(\operatorname{CON}_{i t}\right)$, is 0.1876 , suggesting that the level of firms' financial statements conservatism is at a medium level. The mean of 'taking a big bath' motivation $\left(B A T H_{i t}\right)$ is -0.0175 , the mean of 'earnings smoothing' motivation $\left(\mathrm{SMOOTH}_{i t}\right)$ is 0.0298 , and the average of the variable of the previous recognized asset impairment ratio $\left(I M P_{i t-1}\right)$ is 0.0020 . The mean of the variable of change in average asset return rate $\left(\triangle R O A_{i t}\right)$ was $4.0994 \%$. The VIF value among firm-level variables of the VIF (Variance Inflation Factors) test is below 5 except for $C O N$ is 15 . Thus, multicollinearity should not be a problem in our regression model.

Table 5. Descriptive statistics of variables of $\mathrm{H}_{1}$

\begin{tabular}{|l|c|c|c|c|c|}
\hline \multicolumn{1}{|c|}{ Variable } & Mean & Median & Max & Min & Std. dev. \\
\hline$I M P_{i t}$ & 0.0016 & 0.0000 & 0.4854 & 0.0000 & 0.0124 \\
\hline CON $_{i t}$ & 0.1876 & 0.0000 & 1.0000 & 0.0000 & 0.3904 \\
\hline BATH $H_{i t}$ & -0.0175 & 0.0000 & 0.0000 & -2.4572 & 0.0557 \\
\hline$S M O O T H_{i t}$ & 0.0298 & 0.0000 & 13.8519 & 0.0000 & 0.1665 \\
\hline$I M P_{i t-1}$ & 0.0020 & 0.0000 & 0.7037 & 0.0000 & 0.0172 \\
\hline$\Delta R O A_{i t}(\%)$ & 4.0994 & 4.4767 & 42.7600 & -15.5630 & 9.2342 \\
\hline$\Delta S A L E_{i t}(\%)$ & 9.2025 & 0.0186 & 756.0300 & -1.0000 & 74.1754 \\
\hline$\Delta O C F_{i t}$ & -0.0047 & -0.0000 & 1.4636 & -8.9921 & 0.1957 \\
\hline$M T B_{i t}$ & 1.7184 & 1.2400 & 21.5000 & 0.2100 & 3.5853 \\
\hline$L E V_{i t}$ & 0.0687 & 0.0184 & 0.7150 & 0.0000 & 0.0966 \\
\hline$S I Z E_{i t}$ & 15.3323 & 15.1975 & 21.7924 & 10.0839 & 1.4217 \\
\hline$E L E C_{i t}$ & 0.5092 & 1.0000 & 1.0000 & 0.0000 & 0.4999 \\
\hline
\end{tabular}

Source: authors 


\subsubsection{Test of $H_{1}$ Tobit regression analysis results}

Table 6 shows the results of the multivariate Tobit regression analysis for asset impairment losses and financial statement conservatism. The coefficient for financial statement conservatism $\left(C O N_{i t}\right)$ is insignificantly positive, which meet the expectations. The coefficient of 'taking a big bath' motivation $\left(B A T H_{i t}\right)$ is negative and significant $(\mathrm{p}<0.01)$ and the coefficient of 'earnings smoothing' motivation $\left(S M O O T H_{i t}\right)$ is negative and significant ( $\mathrm{p}<0.01$ ), indicating that when the company's earnings performance is relatively strong, the management will choose to recognize less asset impairment losses. In contrast, when the company has excessive earnings, to avoid too great a fluctuation in earnings, the managers will recognize asset impairment losses, as expected (Yang and $\mathrm{Wu}$ ). In this study, we observed that the interaction term for financial statement conservatism and 'taking a big bath motivation' $\left(B A T H_{i t} * C O N_{i t}\right)$ is negative and insignificant not as expected. The interaction term for financial statement conservatism and earnings smoothing $\left(\right.$ SMOOTH $\left._{i t} * \mathrm{CON}_{i t}\right)$ is 0.0462 , which, significant and is contrary to expectations. Thus, it appears that financial statement conservatism cannot achieve the object of a suppressing effect on taking a big bath and earnings smoothing via recognized asset impairment. Therefore, $\mathrm{H}_{1}$ is not supported.

The coefficient of the prior period asset impairment $\left(I M P_{i t-1}\right)$ is positive and significant $(\mathrm{p}<0.01)$, as expected, indicating that the company will recognize more impairment losses in the current year if it recognized asset impairment in the prior year. The coefficient of change in average assets return rate $\left(\triangle R O A_{i t}\right)$ is -0.001 , indicating a negative relationship at the $1 \%$ significance level. That is, when the company's profitability is relatively poor, the company will recognize more impairment losses to reflect the poor operating performance of the company, as expected.

Table 6. Results of the multivariate Tobit regression analysis

\begin{tabular}{|c|c|c|c|c|}
\hline Variables & $\begin{array}{c}\text { Predicted } \\
\text { sign }\end{array}$ & Coefficient & Z-value & P-value \\
\hline INTERCEPT & $?$ & -0.0958 & $-5.04^{* * *}$ & $0.00^{* * * *}$ \\
\hline $\mathrm{CON}_{i t}$ & + & 0.0011 & 0.43 & 0.66 \\
\hline$B A T H_{i t}$ & - & -0.0579 & $-2.73^{* * *}$ & $0.00^{* * * *}$ \\
\hline SMOOTH $_{\text {it }}$ & + & -0.0093 & $-2.41^{* *}$ & $0.01^{* *}$ \\
\hline$B A T H_{i t} * C O N_{i t}$ & + & -0.0167 & -0.48 & 0.63 \\
\hline SMOOTH $_{i t} * C O N_{i t}$ & - & 0.0462 & $2.22^{* *}$ & $0.02^{* *}$ \\
\hline$I M P_{i t-1}$ & + & 0.1514 & $3.50^{* * * *}$ & $0.00^{* * * *}$ \\
\hline$\Delta R O A_{i t}$ & - & -0.0011 & $-6.59^{* * *}$ & $0.00^{* * * *}$ \\
\hline$\Delta S A L E_{i t}$ & - & $-6.46 \mathrm{E}-06$ & -0.82 & 0.40 \\
\hline$\triangle O C F_{i t}$ & - & 0.0029 & 0.86 & 0.38 \\
\hline$M T B_{i t}$ & - & 0.0001 & 1.26 & 0.20 \\
\hline$L E V_{i t}$ & + & 0.0094 & 1.32 & 0.18 \\
\hline$S I Z E_{i t}$ & $?$ & 0.0028 & $2.79^{* * * *}$ & $0.00^{* * * *}$ \\
\hline$E L E C_{i t}$ & & -0.0011 & -0.86 & 0.38 \\
\hline \multicolumn{5}{|l|}{ YEAR CONTROL } \\
\hline Observations & & 9598 & & \\
\hline Log likelihood & & $334.70^{* * *}$ & & \\
\hline
\end{tabular}




\subsection{Gain on Reversals of Impairment and Financial Statement Conservatism \\ 4.3.1 Descriptive statistics}

Table 7 shows the descriptive statistics of gain on reversals of impairment and financial statement conservatism. First, the mean of gain on reversals of impairment $\left(R E V_{i t}\right)$ is 0.0011 and the average of financial statement conservatism $\left(C O N_{i t}\right)$ was 0.2518 , indicating that samples of high and low levels of conservatism are equal in number. Thus, overall, the level of conservatism is medium. The mean of the prior period recognition of asset impairment $\left(B E_{-} I M P_{i t}\right)$ is 0.0163 , larger than the median of 0.0003 , suggesting that more impairment losses in prior periods were recognized. The average of the dummy variable for the electronics industry $\left(E L E C_{i t}\right)$ is 0.4585 ; that is, companies in the electronics industry accounted for close to $50 \%$ of the total sample.

Table 7. Descriptive statistics of gain on reversals of impairment and financial statement conservatism

\begin{tabular}{lccccc}
\hline & Mean & Median & Max & Min & Std. dev. \\
\hline$R E V_{i t}$ & 0.0010 & 0.0000 & 0.3526 & 0.0000 & 0.0114 \\
$\operatorname{CON}_{i t}$ & 0.2518 & 0.0000 & 1.0000 & 0.0000 & 0.4342 \\
$B_{-} I M P_{i t}$ & 0.0163 & 0.0031 & 0.7037 & $1.13 \mathrm{E}-07$ & 0.0460 \\
$\Delta R O A_{i t}(\%)$ & 0.3983 & 2.1100 & 35.3566 & -66.8600 & 10.4601 \\
$\triangle S A L E_{i t}(\%)$ & 0.2417 & 0.0128 & 73.3126 & -0.9998 & 3.1763 \\
$O C F_{i t}$ & -0.0061 & 0.0006 & 0.7831 & -4.9847 & 0.2023 \\
$M T B_{i t}$ & 2.1268 & 1.2100 & 219.17 & 0.2100 & 8.6061 \\
LEV $_{i t}$ & 0.0797 & 0.0366 & 0.6725 & 0.0000 & 0.1019 \\
IZE $_{i t}$ & 15.4940 & 15.3835 & 21.7924 & 10.0839 & 1.6894 \\
$E L E C_{i t}$ & 0.4585 & 0.0000 & 1.0000 & 0.0000 & 0.4984 \\
\hline
\end{tabular}

Source: authors

\subsubsection{Test of $\mathrm{H}_{2}$ Tobit regression analysis}

Table 8 shows the results of Tobit regression for gain on reversals of impairment and financial statement conservatism. The coefficient of the financial statement conservatism $\left(C O N_{i t}\right)$ is positive but insignificant. The coefficient of prior period asset impairment recognition $\left(B E_{-} I M P_{i t}\right)$ is positive but insignificant, indicating that when the company recognized more impairment in a prior period, the gain on reversals of impairment in a later period will be more. The coefficient of the interaction term of the prior period impairment losses and financial statement conservatism $\left(C O N_{i t} * B E_{-} I M P_{i t}\right)$ is negative and significant $(\mathrm{p}<0.1)$, indicating suggests that when the level of financial statement conservatism is higher, it can reduce the recognition of asset impairment losses in a prior period by a company seeking to 'improve' earnings by recognized more gain on reversals of impairment in a later period, making it unable to truly express the business operating conditions of the company. Therefore, $\mathrm{H}_{2}$ is supported.

For the control variables, the coefficient of change in average asset return rate $\left(\triangle R O A_{i t}\right)$ is negative and significant $(\mathrm{p}<0.01)$, means that the company will recognize less gain on reversals of impairment to improve the earnings of the company, to comply with investor expectations of the company when the profitability of the company is growing. 
Table 8. The results of Tobit regression

\begin{tabular}{|l|l|c|c|c|}
\hline \multicolumn{1}{|c|}{ Variables } & Predicted sign & coefficient & Z-value & P-value \\
\hline INTERCEPT & ? & -0.0448 & -1.91 & 0.05 \\
\hline$C O N_{i t}$ & - & 0.0045 & 0.75 & 0.44 \\
\hline$B E_{-} I M P_{i t}$ & + & 0.0783 & 1.32 & 0.18 \\
\hline$C O N_{i t} * B E_{-} I M P_{i t}$ & - & -0.2874 & $-1.66^{*}$ & $0.10^{*}$ \\
\hline$\triangle R O A_{i t}$ & + & -0.0005 & $-2.53^{* * *}$ & $0.01^{* * *}$ \\
\hline$\triangle S A L E_{i t}$ & + & 0.0002 & 0.71 & 0.47 \\
\hline$\triangle O C F_{i t}$ & + & 0.0108 & 1.44 & 0.14 \\
\hline$M T B_{i t}$ & + & -0.0003 & -1.35 & 0.17 \\
\hline$L E V_{i t}$ & + & -0.0012 & -0.09 & 0.92 \\
\hline$S I Z E_{i t}$ & + & $-8.93 \mathrm{E}-05$ & -0.05 & 0.95 \\
\hline$E L E C_{i t}$ & $\mathbf{P}$ & -0.0067 & -1.76 & 0.07 \\
\hline Observations. & & 1219 & & \\
\hline Log likelihood & & $18.982^{* * *}$ & & \\
\hline
\end{tabular}

Source: authors

\section{CONCLUSIONS}

In this study, we investigate the relationship between accounting conservatism and asset impairment. $\mathrm{H}_{1}$ explored whether accounting conservatism and the company's financial statement conservatism can affect the company's motivations for asset impairment recognition, and it was expected that a higher financial statement conservatism level could suppress the motivation for earnings management. This study tests both the motivation of taking a big bath and the motivation of earnings smoothing. The empirical results show that higher financial statement conservatism had no significant impact on the recognized impairment losses due to the taking a big bath motivation or the earnings smoothing motivation. Thus, $\mathrm{H}_{1}$ was not supported.

$\mathrm{H}_{2}$ explored whether the level of a company's financial statement conservatism can affect the relationship between earlier recognized impairment losses and gain on reversals of impairments recognized later. The empirical results showed that a higher financial statement conservatism level can reduce management's manipulation of recognized more prior impairment losses and more gain on reversals of the impairment recognized in a later period. Therefore, $\mathrm{H}_{2}$ was supported.

The empirical results show that a higher accounting conservatism level can reduce management manipulation for recognized more impairment losses in the prior period and then more gains on impairment reversal.

With total amounts of asset impairment as the measurement variable, follow-up studies may further compare different types of assets, the relationship between the motivations for the recognized impairment losses or gains on reversals of impairment and financial statement conservatism. 


\section{RREFERNCES}

Basu, S. (1997). The conservatism principle and the asymmetric timeliness of earnings. Journal of Accounting and Economics, 24 (December), 3-37. https://doi.org/ 10.1016/S0165-4101(97)00014-1

Chang Y.Y. (2006). Conservatism, assets impairment, and the agency problem of ownership. Working Paper, Soochow University.

Chang, M. L., \& Yen, T. Y. (2015). Does Reversal of Asset Impairment Loss Matter? Evidence from China. International Research Journal of Applied Finance, 6(4), 197-222.

Chen, J.P., Chen, S., Su, X., \& Wang, Y. (2004). Incentives for and consequences of initial voluntary asset write-downs in the emerging Chinese market. Journal of International Accounting Research, 3(1), 43-61. https://doi.org/10.2308/ jiar.2004.3.1.43

Chen, S., Wang, Y., \& Zhao, Z. (2007). Evidence of asset impairment reversals from China: Economic reality or earnings management? Working Paper, The Hong Kong Polytechnic University.

Dorina, L., \& Sorin, G. (2016). Continental And International Normalization Of Asset Impairment. Management Strategies Journal, 31(1), 83-89.

Duh, R.R., Lee, W.C., \& Lin, C.C. (2009). Reversing an impairment loss and earnings management: The role of corporate governance. The International Journal of Accounting, 44, 113-137. https://doi.org/10.1016/j.intacc.2009.03.001

Financial Accounting Standards Board (FASB). (1980). Qualitative Characteristics of Accounting Information. Statement of Financial Accounting Concepts no. 2. FASB, Norwalk, CT.

Financial Accounting Standards Board (FASB). (2004). Accounting Treatment of Asset Impairment. Statement of Financial Accounting Standards No. 35. Taipei, Taiwan: FASB.

Francis, J., Hanna, J., \& Vincent, L. (1996). Causes and effects of discretionary asset write-offs. Journal of Accounting Research, 34 (Supplement), 117-134. https://doi.org/10.2307/2491429

International Accounting Standards Board (IASB). (2004). Impairment of Assets. International Accounting Standards No. 36. London, UK: IASB.

Khan, M., \& Watts, R. (2009). Estimation and empirical properties of a firm-year measure of accounting conservatism. Journal of Accounting and Economic, 48(December), 132-150. https://doi.org/10.1016/j.jacceco.2009.08.002

Kao, L.F., Chen, Y. K., \& Chen, M. L. (2011). Agency Problems and Accounting Conservatism. International. Journal of Accounting Studies, 52, 103-136.

LaFond, R., \& Watts, R. L. (2008). The Information Role of Conservatism. The Accounting Review, 83(February), 447-478.

Levitt, A. (1998). The importance of high quality accounting standards. Accounting Horizons, $12,79-82$.

Lin, M. F., Chin, C. L., \& Lin, L. F. (2009). Ownership Structures, Accounting Conservatism and Firm's Credit Ratings. NTU Management Review, 20(1), 289-330.

Riedl, E. J. (2004). An examination of long-lived asset impairments. The Accounting Review, 79 (July), 823-852.

Rees, L., Gill, S., \& Gore, R. (1996). An investigation of asset write-downs and concurrent abnormal accruals. Journal of Accounting Research, 34(Supplement), 157-169. https://doi.org/10.2307/2491431

Rennekamp, K., Rupar, K. K., \& Seybert, N. (2014). Impaired judgment: The effects of asset 
impairment reversibility and cognitive dissonance on future investment. The Accounting Review, 90(2), 739-759. http://dx.doi.org/10.2139/ssrn.2133520

Watts, R. L. (2003). Conservatism in Accounting Part I: Explanations and Implications. Accounting Horizon, 17(September), 207-221. http://dx.doi.org/10.2139 /ssrn.414522

Zhang, R., Lu, Z., \& Ye, K. (2010). How do firms react to the prohibition of long-lived asset impairment reversals? Evidence from China. Journal of Accounting and Public Policy, 29(5), 424-438. https://doi.org/10.1016/j.jaccpubpol.2010.09.010

Zucca, L., \& Campbell, D. (1992). A closer look at discretionary write-down of impaired assets. Accounting Horizons, 6 (September), 30-41. 